\title{
Development of Digital Tools for Managing Cooperative Interaction Between Defense Industry Enterprises
}

\author{
Kseniya S. Kochetova ${ }^{1 *[O R C I D}$ 0000-0001-9625-3130], \\ Elena V. Kulyasova 1[ORCID 0000-0001-9430-3368]
}

\author{
${ }^{1}$ All-Russia Scientific and Research Institute "Center”, Moscow, Russia \\ kochetovaKS@inform-teh.ru
}

\begin{abstract}
The modern production of weapons, military and special equipment is characterized by a high level of material and science intensity, the involvement of a large number of scientific and industrial organizations in the production process, the geographical remoteness of enterprises from each other, which requires the improvement of existing management mechanisms. External political instability as well as the ongoing change of technological structures in the economy also complicate the production activities of enterprises of the defense industry. The article analyzes the problematic issues of managing the cooperative interaction between defense industry enterprises, caused by the development of forms of inter-factory cooperation in the manufacture of weapons, military and special equipment, and also identifies guidelines that make it possible to effectively plan and coordinate the production activities of all actors involved in the implementation of the State Defense Order. As part of the study, a comparative analysis of the functionality of automated production process management systems used by defense industry enterprises has been carried out, which made it possible to identify a list of cooperation management tasks not covered by existing systems. Based on the results of the study, an automated information system for managing inter-factory cooperation has been proposed, the implementation of which will create a single information and analytical space for all participants in the manufacture of samples of weapons, military and special equipment. The article presents a conceptual scheme of this system, describes its functionality and main users. The structure of an automated management system for inter-factory cooperation is described, which consists of six modules: defense industry enterprises logistics, planning the production of samples of weapons, military and special equipment, defense industry enterprises' production capacity management, contracting management, normative reference data, the integration of the system with ERP- and PLM-systems of enterprises and departmental information systems. The article outlines the practical significance of the proposed digital management tool, describes the management tasks solved on its basis, and the expected effects of its implementation in the defense industry.
\end{abstract}

Keywords: industrial cooperation, management of cooperative interaction, defense industry (DI), weapons, military and special equipment (WMSE), automated information system (AIS)

\section{INTRODUCTION}

The observed growth of geopolitical and geoeconomic instability, the increasing level of external and internal threats, the rapid development of scientific and technological progress dictates the need to solve new problems both in the development of modern weapons, military and special equipment (hereinafter - WMSE), and in the field of ensuring national security of the Russian Federation. These trends were noted at the end of 2019 by the President of the Russian Federation V.V. Putin at a meeting of the Security Council and became the basis for the formation of the State armament program of the Russian Federation, as well as the state program "Development of the defense industrial complex" for the new program period until 2033. Among the main tasks, the need to increase the level of production, technological, materialtechnical, and personnel readiness of organizations 
of the defense industry (hereinafter - DI) for the development and serial production of modern weapons and equipment was highlighted [1].

Achieving the goal of increasing the level of production and technological readiness of the DI as one of the most high-technology segments of the domestic industries is associated with the solution of two main tasks. One of them is the involvement of a wide range of DI organizations, such as research institutes, design bureaus, manufacturing enterprises, and others in the process of creating and manufacturing modern samples of WMSE, which requires coordination of production processes, management of resources and logistics for timely production of the required amount of military equipment.

Today, in order to ensure the growth and sovereignty of the Russian economy amid fluctuations in the global arena and the growth of sanction pressure, our country is faced with the fact of the need to accelerate the pace of modernization and change the paradigm of economic development. This implies the need to solve the second complex task, which consists in generating new knowledge and ideas that stimulate the development of new technologies and are embodied in innovations being introduced, digitalization tools, which are the result of organized network interaction among many participants [2].

In this regard, in the author's opinion, the development of cooperation processes and linkages between the enterprises of the DI acquires special relevance. In the works of Russian scientists V. Vlasova and V. Roud, the development of cooperative linkages is presented as a fundamental element of activities aimed at forming a system approach to innovative development, both within an individual enterprise and within the country as a whole [3]. A similar hypothesis is put forward and defended by such foreign economists as C. Edquist and J. Fagerberg in their works [3, 4]. From the above, we can conclude that cooperation provides not only an increase in competitiveness, sustainable and innovative development, but also an increase in economic security both at the level of an economic entity and at the level of the national economy as a whole.

\section{MATERIALS AND METHODS}

The purpose of this study is the development of digital tools that allow solving problems of managing the cooperative interaction between DI enterprises in the production of samples of WMSE in modern realities in order to increase production efficiency, increase the competitiveness of products and minimize the disruption of the delivery time of the State Defense Order (hereinafter - SDO).

The achievement of this goal is ensured by solving the following tasks:

- to analyze the factors that complicate the cooperative interaction between DI enterprises and affect the possible occurrence of delays in the implementation of the SDO;

- to identify problematic issues of management arising in the planning and coordination of work on the manufacture of samples of WMSE at the enterprises of the DI;

- to study the shortcomings of digital management tools used in the coordination of work on the implementation of the SDO;

- to develop a conceptual structure of an automated information system (hereinafter AIS) for solving problems of management of inter-factory cooperation, which allows planning, monitoring, coordination, and control of the production process at all enterprises involved in the manufacture of WMSE samples.

When performing this study, the methods of descriptive, statistical, logical, comparative analysis were applied, which allowed the authors to solve the set research tasks.

The problematic management issues described in the study, as well as the proposals presented in the article, are based on data from surveys of DI organizations conducted since 2018 by the Scientific and Technical Center "Informtechnika", a branch of the Federal State Unitary Enterprise All-Russia Scientific and Research Institute "Center". The results of one of the latest studies in the field of digitalization have shown the presence of a low level of automation of management tasks for inter-factory cooperation in more than $83 \%$ of the DI enterprises out of 198 respondents [5].

The informational basis of the study was also made up of data from regulatory legal acts, state executive bodies, federal reference books and statistical collections, materials of foreign and Russian scientific works.

\section{RESULTS}

With an increase in the level of the technological effectiveness and science intensity of production, the 
emergence of new technologies, the process of production of military equipment becomes more complicated, which makes it less flexible and adaptable to changes in the external environment, and also requires the improvement of the management tools used. According to the author, the use of cooperation will make it possible to overcome the sectoral isolation of DI organizations and to expand bottlenecks in production.

In addition, the rate of increase in the production of new technologies is much higher in the presence of cooperative linkages than the industry average. Thus, according to the source [6], scientific and industrial cooperation is mainly characteristic of innovatively active organizations aimed at the production of competitive products.

The share of industrial organizations engaged in joint development and implementation of technological innovations (based on cooperative interaction) amounted to $17.6 \%$ in 2019 , and in the high-technology industry sector, this figure reached $30.8 \%$ (Figure 1).

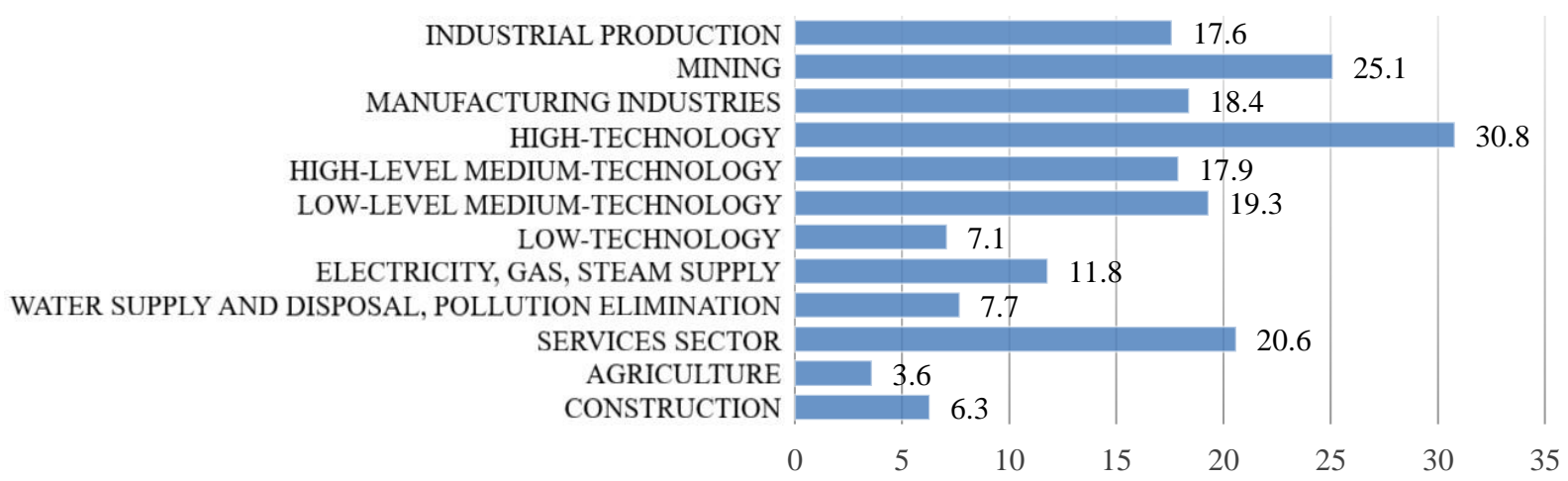

Figure 1. Percentage of organizations participating in joint research and development work in 2019 by economic sector

Source: [7]

Turning to the background of the issue, the task of building cooperative linkages is not new for the domestic DI. Even in the USSR, great importance was attached to the solution of this problem. The structure that played a special role in solving problems of managing cooperative interaction in the DI was the Military-Industrial Commission of the USSR (hereinafter - the VPK under the Council of Ministers of the USSR). The VPK under the Council of Ministers of the USSR coordinated the work on the creation of modern types of weapons and military equipment, as well as coordinated the work of the defense sectors, other ministries, and departments of the USSR involved in the creation and production of WMSE.

Recently, the Russian Federation has also begun to pay special attention to the creation and development of cooperative structures in the DI. At the beginning of 2020, 41 integrated (holding) structures were formed in the structure of the domestic DI, which concentrated more than $80 \%$ of the DI production capacity. The main backbone enterprises of the DI are united into 23 integrated structures operating directly under the jurisdiction of the Ministry of Industry and Trade of Russia, including 15 within the Rostec State Corporation, as well as in 11 subsidiary holdings of the Roscosmos
State Corporation. These integrated structures include about 600 enterprises and organizations in the DI [8].

It should be noted that attention is paid to cooperation processes in the DI not only within the framework of the functioning of integrated structures but also within the framework of the implementation of the provisions of a number of state programs, such as the state armament program and the state program "Development of the militaryindustrial complex". It should also be noted that within the framework of the implementation of state programs, budgetary funding is allocated and aimed at enhancing innovation and increasing the competitiveness of DI organizations.

Summarizing the above-described stages of building and developing cooperative linkages in the USSR and the Russian Federation, one should dwell separately on the fact that in the course of their functioning a problem arises associated with solving the task of efficiently managing the cooperative interaction of DI organizations. Taking into account the fact that the modern development of the DI is associated with the growth of high-technology production, and the creation of promising samples of WMSE requires active development of innovative 
activities, the cooperative interaction of DI organizations is constantly becoming more complicated.

In this regard, the authors propose to consider such a form of building competitive associations among the interacting enterprises of the DI, as production cooperation which allows maintaining the rhythm and planned delivery of WMSE samples both for the internal needs of the armed forces and for export, as well as developing innovative types of weapons and implementing DI diversification programs.

Taking into account the tendency of uniting DI enterprises into vertically integrated corporate structures, the problem arises of finding effective tools to solve the tasks of managing cooperative interaction between DI organizations and enterprises, while it is necessary to pay attention to such key aspects of cooperation as planning and control of all links of the production process. Taking these aspects into account will allow DI enterprises to switch to modern and digital models of doing business, and in the future to solve the problems of optimizing the production capacities of enterprises and using them to diversify production [9]. According to the authors, the successful implementation of this transition will require solving the problems of creating distributed production systems united by a network of virtual digital communications, and managing the cooperative interaction among enterprises that are links of the cooperative network $[10,11]$.

Analyzing the problems of managing cooperative interaction presented in Figure 2, the authors consider that, in the context of the relevance of the topic of this article, special attention should be paid to the problem of production desynchronization and discreteness in the procedure for harmonizing the volumes and timing of the production of military products between DI organizations within the framework of several levels of cooperation.

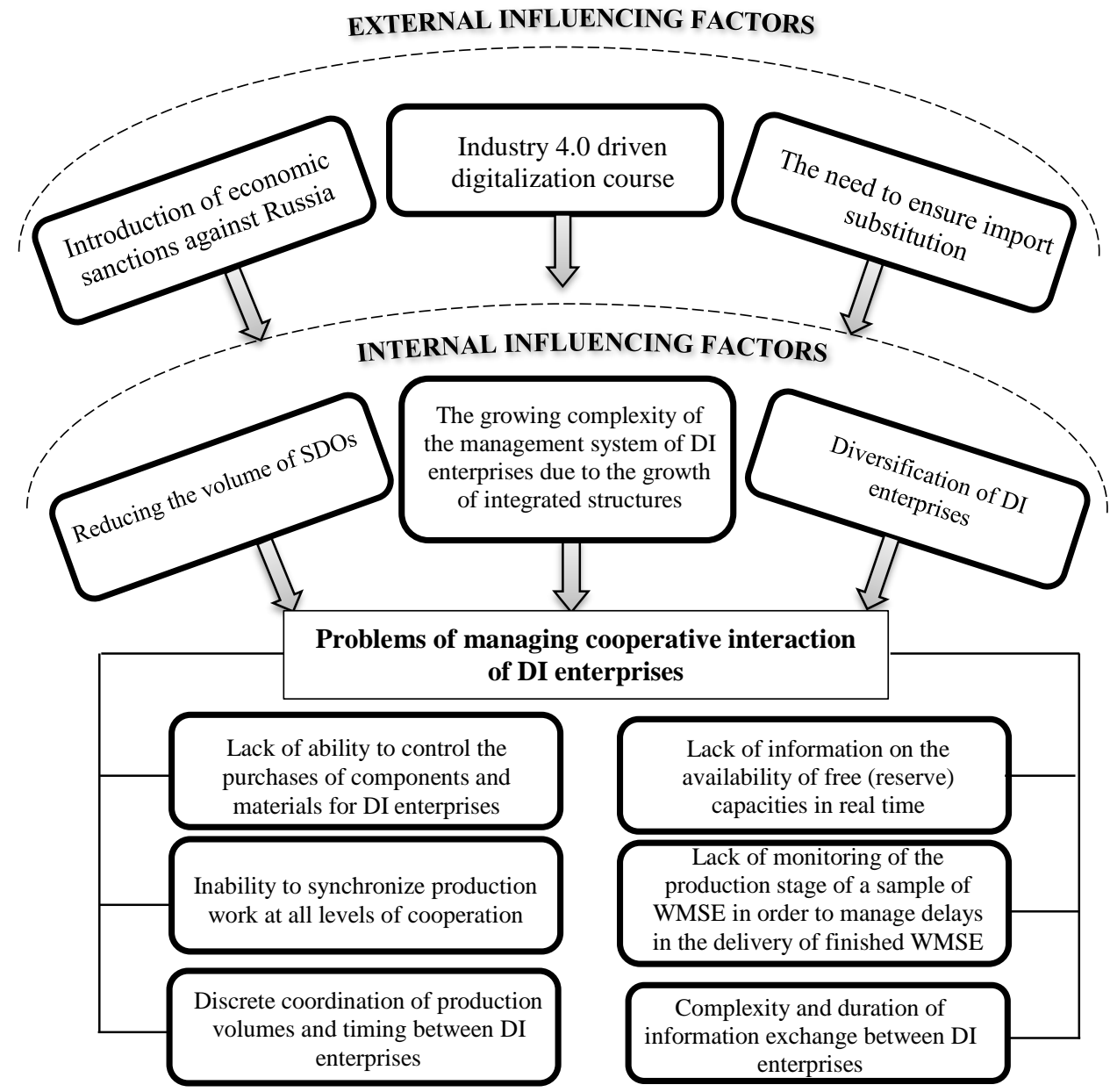

Figure 2. A list of the existing problems of managing the cooperative interaction between DI enterprises and the factors affecting their occurrence

Source: Compiled by the authors 
This problem is a logical consequence of the economic independence of an individual enterprise within the framework of a cooperative structure. The problem identified above leads to the fact that the parent organization does not have up-to-date data on the available free production capacity and information on the phasing of orders at each specific enterprise participating in inter-factory cooperation, which makes it impossible to assess the timeliness of order fulfillment. The presence of this problem is especially acutely felt at the final stages of the life cycle of manufacturing a sample of WMSE when it is often economically inexpedient to take any managerial measures to correct the current situation.

One of the options for solving the indicated problem in managing the cooperative interaction between DI enterprises can be the use of an AIS to solve the problems of managing the production process and production cooperation of DI enterprises.

\section{DISCUSSION}

AISs for managing the production process and production cooperation, used at the enterprises of the DI at the moment, are not able to provide the necessary level and depth of synchronization of all production indicators of enterprises, taking into account their possible deviations and the likelihood of disruption of production plans for the supply of WMSE samples. The above-described shortcomings of the existing AISs for managing the production process and production cooperation at DI enterprises indicate the need for the creation, implementation, and development of an AIS that allows solving the problems of managing inter-factory cooperation, using methods of forecasting and monitoring the dynamics of the current state of the production plan of an individual DI enterprise within the framework of the life production cycle of WMSE.

The management system proposed for implementation to solve problems of management of inter-factory cooperation has wide functionality and differs significantly from the functionality of the AISs for managing production activities currently installed at DI enterprises (Table 1).

The main tasks that the proposed system can solve can be structurally combined into the following modules:

1) The module of logistics of the DI enterprises participating in the SDO;

2) The module for WMSE sample production planning;

3) The module for managing the production capacities of DI enterprises;

4) Contracting management module;

5) Normative reference data (hereinafter NRD) module;

6) The module of AIS integration with ERPand PLM-systems of enterprises and departmental AISs (MISs).

Table 1. Comparison of the AIS functionality for managing production processes installed at DI enterprises

\begin{tabular}{|c|c|c|c|}
\hline Name of Subsystems and Functions Performed & Galaktika: ERP & 1C: ERP & Proposed AIS \\
\hline Production planning & $\checkmark$ & $\checkmark$ & $\mathrm{X}$ \\
\hline Maintaining product specifications & $\checkmark$ & $\checkmark$ & $\checkmark$ \\
\hline Maintaining the cooperative composition and scheme of cooperation & $\mathbf{X}$ & $\mathbf{X}$ & $\checkmark$ \\
\hline Production capacity planning & $\checkmark$ & $\checkmark$ & $\mathbf{X}$ \\
\hline Incoming/outgoing quality control & $V$ & $\checkmark$ & $\mathbf{X}$ \\
\hline Resource planning & $\checkmark$ & $\checkmark$ & $\mathbf{x}$ \\
\hline The function of cross-sectoral standardization and NRD unification & $\mathbf{X}$ & $\mathbf{X}$ & $V$ \\
\hline Contracting management & $\mathbf{X}$ & $\mathbf{X}$ & $\checkmark$ \\
\hline Planning work for all levels of cooperation & $\mathbf{x}$ & $\mathbf{x}$ & $\checkmark$ \\
\hline $\begin{array}{l}\text { Management of the development and implementation of cooperation } \\
\text { schedules }\end{array}$ & $\mathbf{X}$ & $\mathbf{X}$ & $\checkmark$ \\
\hline Accounting for capacity utilization when planning cooperation & $\mathbf{X}$ & $\mathbf{X}$ & $\checkmark$ \\
\hline Maintaining the cooperative composition and cooperation schemes & $\mathbf{X}$ & $\mathbf{X}$ & $\checkmark$ \\
\hline Logistics management & $\checkmark$ & $\checkmark$ & $\checkmark$ \\
\hline Functions ensuring the operation of the system in protected mode & $\mathbf{X}$ & $\mathbf{X}$ & $\checkmark$ \\
\hline Functions of integration with industry and external systems & $\mathbf{X}$ & $\mathbf{X}$ & $\checkmark$ \\
\hline $\begin{array}{l}\text { Maintaining NRD for the unification of planning and control over the } \\
\text { execution of plans at the enterprises of the DI }\end{array}$ & $\mathbf{X}$ & $\mathbf{x}$ & $\checkmark$ \\
\hline
\end{tabular}

Source: Compiled by the authors

The launch of this system at all enterprises participating in inter-factory cooperation for manufacturing WMSE samples will allow:
- to carry out the automatic formation of consolidated schedules for the supply of materials, components, finished units to 
enterprises, taking into account the manufacturing cycle of WMSE;

- to automatically track the timing of purchases, shipments, conclude contracts with customers and suppliers, track financial transactions on them and the timing of their implementation;

- to receive operational information in an automated mode about the current state of work on the manufacture of a sample of
WMSE from all enterprises participating in the cooperation.

The introduction and industrial development of the proposed AIS will allow DI enterprises to achieve significant results, the main ones among will be the following (Figure 3):

- risk management on failure to meet the deadlines for fulfilling orders for the implementation of the SDO;

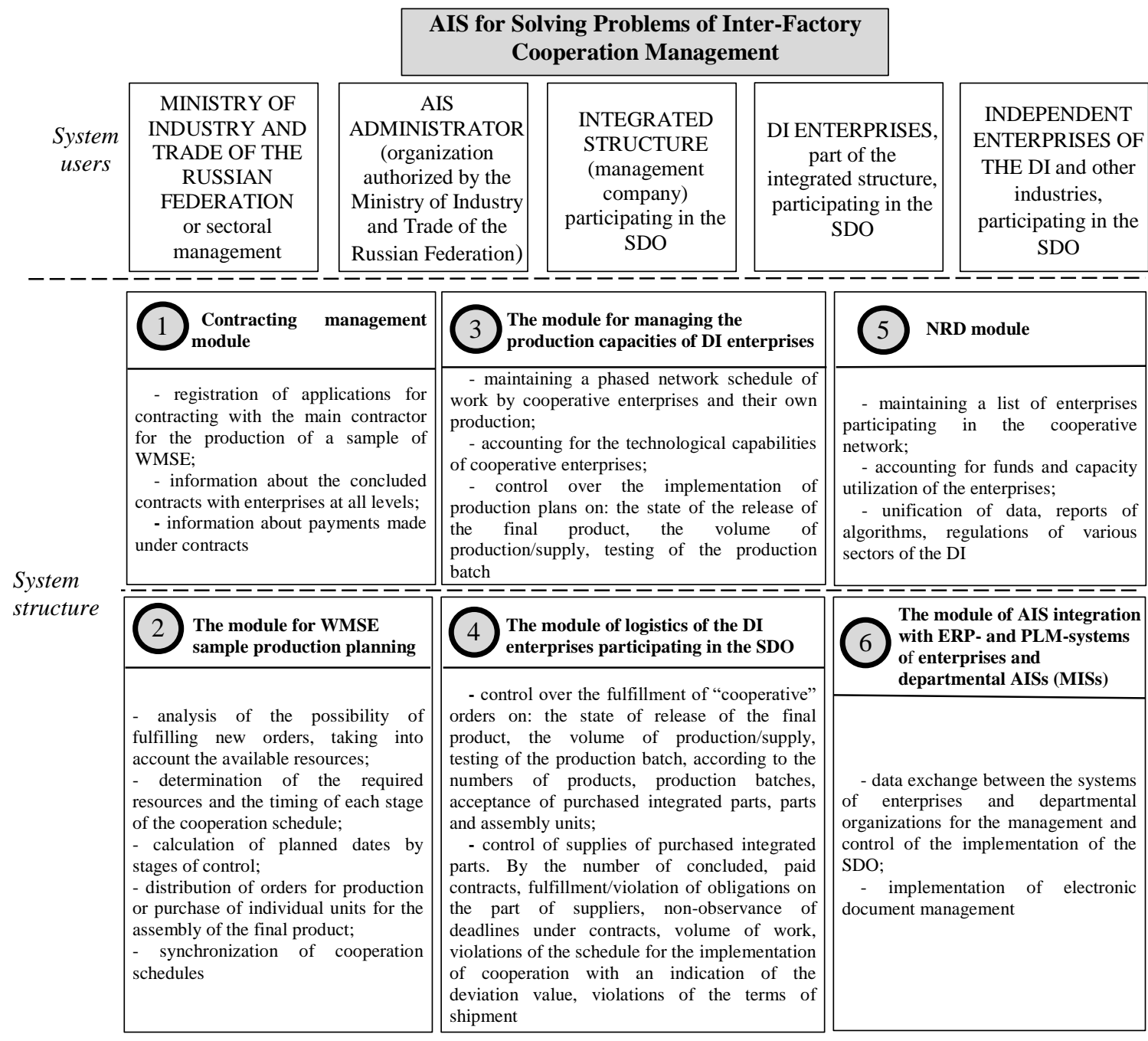

Timely prevention of failure to meet the deadlines for fulfilling orders for the implementation of the SDO

\begin{tabular}{l|l|l|c|c|}
\cline { 2 - 4 } $\begin{array}{l}\text { Expected } \\
\text { effects of }\end{array}$ & $\begin{array}{c}\text { Obtaining a resource model of DI } \\
\text { enterprises participating in the } \\
\text { creation of samples of WMSE }\end{array}$ & $\begin{array}{c}\text { Ensuring the prompt redistribution of } \\
\text { equipment load in the event of an } \\
\text { unplanned outage }\end{array}$ & $\begin{array}{c}\text { Reducing the number of errors and } \\
\text { delays in the preparation of } \\
\text { documentary and financial support }\end{array}$ \\
\cline { 2 - 4 } system & $\begin{array}{c}\text { Integration with } \\
\text { production and } \\
\text { industry systems }\end{array}$ & $\begin{array}{c}\text { Optimization of production capacities of } \\
\text { cooperative enterprises, taking into } \\
\text { account the pool of orders and time frames }\end{array}$ & $\begin{array}{c}\text { Implementation of current monitoring of } \\
\text { indicators of the state of production and } \\
\text { orders for all enterprises of the cooperation }\end{array}$ \\
\cline { 2 - 3 } &
\end{tabular}

Figure 3. The conceptual structure of an AIS for solving problems of inter-factory cooperation management Source: Compiled by the authors 
- ensuring the management and synchronization of the work of all enterprises involved in the manufacture of a sample of WMSE in an automated system in real time;

- ensuring the efficient use of the production capacities of the DI enterprises;

- replacement of human resources with an automated system in terms of collecting data on enterprises, manual preparation of documents for contracting, which reduces the number of errors caused by the "human" factor, and also allows for the timely preparation of documentary and financial support for work [12].

\section{CONCLUSION}

The expansion of the scale and depth of cooperative interaction between DI enterprises complicates the process of managing cooperative chains within the industry, which can lead to disruption of the deadlines for completing SDO assignments. The analysis of the existing problems of managing the cooperative interaction of DI enterprises caused by the development of forms of inter-factory cooperation in the manufacture of WMSE samples has made it possible to identify problematic issues that require special attention and improvement of existing management tools.

To solve new problems in managing the cooperative interaction of DI enterprises, the authors propose the creation of an AIS that allows:

- to provide a single information and digital space between all enterprises and organizations of the DI involved in the manufacture of WMSE samples;

- to coordinate production plans at the DI enterprises for the manufacture of WMSE samples;

- to redistribute production capacities at the enterprises in the event of a shortage or equipment failure at one of the enterprises participating in the cooperative chain for the production of WMSE samples;to solve problems on the management of contracting processes for the timely conclusion of contracts with suppliers, for tracking financing and supplies, etc.

Thus, the use of this system will allow solving the tasks of both tactical management - planning and coordination of production activities at the DI enterprises involved in the manufacture of WMSE samples, and strategic management - the timeliness of fulfilling orders within the SDO.

\section{AUTHORS' CONTRIBUTIONS}

The authors have made equal contributions to the study which includes research concept development; material collection and its analysis; definition of goals and objectives, research methods; formulation and scientific substantiation of conclusions; presentation of key research results in the form of an article.

\section{REFERENCES}

[1] "Materials of the meeting of the Security Council of the Russian Federation", Official website of the President of the Russian Federation. (In Russ.). Retrieved from http://www.kremlin.ru/events/president/transcri pts/62096

[2] P.C. Verhoef, T. Broekhuizen, Ya. Bart, et al., "Digital transformation: A multidisciplinary reflection and research agenda", Journal of Business Research, 2021, vol. 122, pp. 889-901. DOI: 10.1016/j.jbusres.2019.09.022

[3] V. Vlasova, V. Roud, "Cooperative Strategies in the Age of Open Innovation: Choice of Partners, Geography and Duration", Foresight and STI Governance, 2020, vol. 14(4), pp. 80-94. (In Russ.). DOI: 10.17323/2500-2597.2020.4.80.94

[4] C. Edquist, "Design of innovation policy through diagnostic analysis: Identification of systemic problems (or failures)", Industrial and Corporate Change, 2011, vol. 20(6), pp. 17251753. DOI: $10.1093 /$ icc/dtr060

[5] K.S. Balyuk (Kochetova), "Evaluation of the efficiency of implementation of investment projects of optic companies, taking into account the level of digitalization", in Proceedings of the "Economic aspects of digital transformation of industry”, 2020, pp. 20-23. (In Russ.).

[6] O. Zakharkin, I. Basantsov, Iu. Myroshnychenko, et al., "Analysis of the innovative development directions for industrial enterprises", Revista ESPACIOS, 2019, vol. 40(27), pp. 16-25.

[7] L.M. Gokhberg, K.A. Ditkovsky, E.I. Evnevich, et al., "The science. Technologies. Innovation: 2021: A Brief Statistical Compendium" [Nauka. Tekhnologii. Innovatsii: 2021: kratkiy statisticheskiy sbornik] Moscow: National 
Research Institute Higher School of Economics Publishing House, 2021. (In Russ.).

[8] Federal directory. Defense-industrial complex: information and analytical publication [Federal'nyy spravochnik. Oboronnopromyshlennyy kompleks: informatsionnoanaliticheskoye izdaniye], Moscow: Center for Strategic Programs, 2019, vol. 15. (In Russ.).

[9] A. Caspari, C. Tsay, A. Mhamdi, et al., "The integration of scheduling and control: Top-down vs. bottom-up", Journal of Process Control, 2020, vol. 91, pp. 50-62.

[10]T.L.J. Broekhuizen, O. Emrich, M.J. Gijsenberg, et al., "Digital platform openness: Drivers, dimensions and outcomes", Journal of Business Research, 2021, vol. 122, pp. 902-914. DOI: 10.1016/j.jbusres.2019.07.001

[11]Z. Van Veldhoven, J. Vanthienen, "Digital transformation as an interaction-driven perspective between business, society, and technology", Electron Markets, 2021. DOI: https://doi.org/10.1007/s12525-021-00464-5

[12] K.H.J. Hafseld, B. Hussein, A.B. Rauzy, “An attempt to understand complexity in a government digital transformation project", International Journal of Information Systems and Project Management, 2021, vol. 9(3), pp. 70-91. DOI: 10.12821/ijispm090304

[13]D. Lyamshev, "Digital models of management of cooperative production. Origins and development opportunities" [“Tsifrovyye modeli upravleniya kooperatsionnym proizvodstvom. Istoki vozniknoveniya i vozmozhnosti razvitiya”], Production management [Upravleniye proizvodstvom], 2021. (In Russ.). Retrieved from http://www.uppro.ru/library/information_systems/management /cyfrovye-modeli-proizvodstvo.html

[14] O.N. Masko, D.V. Gorlenkov, "Analysis of the state of automation of material flow control in silicon production", Computing, Telecommunications and Control, 2020, vol. 13(4), pp. 66-77. DOI: 10.18721/JCSTCS.13406

[15]D. Schallmo, C.A. Williams, L. Boardman, "Digital transformation of business models Best practice, enablers, and roadmap", International Journal of Innovation Management, 2017, vol. 21(08). DOI: https://doi.org/10.1142/s136391961740014x 